\title{
JEREMIAH 31:34, NEW COVENANT MEMBERSHIP, AND BAPTISM ${ }^{1}$
}

\author{
Christian Locatell \\ Department of Ancient Studies \\ Stellenbosch University
}

\begin{abstract}
The promise of Jeremiah 31:34 that "all of them will know me, from the least of them to the greatest of them," has been of crucial importance for the paedo-vs. credobaptism debate. However, there has been little discussion of what the quantifier means based on Jeremiah's repeated and thematically linked uses. Throughout his prophecy, Jeremiah consistently uses this quantifier in reference to a group about which something is pervasively, though not exhaustively, true. Therefore, the quantifier in Jeremiah 31:34 should not be understood as presenting subjective knowledge of the Lord as the necessary condition of New Covenant membership to the exclusion of infant membership in that community and infant baptism as the sign of membership.
\end{abstract}

Key Words: Baptism; New Covenant; Ecclesiology; Sacramentology; Jeremiah 31

\section{Introduction}

While there are many complex issues in the baptism debate, the nature of the New Covenant community - whether it is mixed or purely regenerate - seems to be at its heart. And perhaps the single most important text (at least in the Old Testament) for this issue is the New Covenant promise in Jeremiah 31:34 that "all of them will know me, from the least of them to the greatest of them." If, as credobaptism maintains, this promises a completely regenerate New Covenant community where all members, without exception, know the Lord, then the infants of believing parents cannot be counted as members and should not receive the sign of membership (baptism). ${ }^{3}$ If, however, as paedobaptism maintains, the New Covenant community continues to be mixed, then this objection fails.

The goal of this article is not to present a comprehensive interpretation of Jeremiah $31: 34$, nor to deal with every issue raised by that text. ${ }^{4}$ Rather, the aim is to present an understanding of the quantifier "all of them ... from the least of them to the greatest of them" that is more contextually informed than common uses of this text in the baptism

1 I would like to thank Professors David VanDrunen, John Fesko, and Christo van der Merwe, as well as two anonymous reviewers, for their helpful comments on a previous version of this article. Any deficiencies remain my own. I would also like to thank Dan Warn for valuable research assistance.

Translations are the author's.

It also important to note that a credobaptist reading of this text applies the quantifying phrase "all of them ... from the least of them to the greatest of them" to every New Covenant blessing listed in Jeremiah 31:31-34. These are commonly delineated as including (1) the law of God written on the heart, (2) saving knowledge of God, and (3) the forgiveness of sins. Therefore, the credobaptist claim that these benefits extend to every New Covenant member without exception also depends on their understanding of this quantifying phrase. See, for example, Fred A Malone, The Baptism of Disciples Alone: A Covenantal Argument for Credobaptism Versus Paedobaptism (revised and expanded, 2nd edition; Cape Coral, FL: Founders Press, 2008:84, 87-90.

4 A detailed historical account of Jeremiah's context and the textual history of the book are beyond the scope of this article and do not seem crucial for the present discussion. For these issues, see the treatments in the standard academic commentaries, several of which are listed in the bibliography of this article. 
debate. This article is also not a case for paedobaptism per se. Rather, it is argued that a more contextually informed interpretation of this phrase in Jeremiah 31:34 reveals that it does not actually present a necessary condition of New Covenant membership, and therefore cannot be used as an argument against paedobaptism. In fact, this contextually informed interpretation turns out to be more consistent with the notion of a mixed New Covenant community. Therefore, the credobaptist will now have to account for why Jeremiah describes the New Covenant community with a phrase that he exclusively uses to designate a mixed group.

\section{Jeremiah 31:34 and the Baptism Debate}

The centrality of this text to the baptism debate is made evident by representative writings from each major camp. The following is not an extensive review of the literature. References from some of the most popular texts on the subject will suffice to make the point. Reformed paedobaptist authors are aware - sometimes bashfully - of the key role this text plays in the debate. ${ }^{5}$ For example, Pratt notes the apparent problem that Jeremiah 31:34 poses for the paedobaptist position:

In effect, infant baptism introduces unregenerate, unbelieving people into the new covenant community. But this practice appears to contradict Jeremiah's prophecy that salvation will be fully distributed in the new covenant. How can it be right for infants to receive the covenant sign of baptism when they often do not and may never "know the Lord"? ${ }^{6}$

Along these same lines, approximately a third of Geerhardus Vos's chapter on the Covenant of Grace in his Reformed Dogmatics is devoted to the problem of whether it includes non-elect members. ${ }^{7}$ In answering the question "With whom is the covenant of Grace established?" Vos, citing Jeremiah 31:31-34, answers, "between God and the elect."8

$5 \quad$ Neil GT Jeffers notes, "In response, paedobaptists have often appeared to be on the defensive, almost apologetically massaging the text to permit infant baptism" (Neil GT Jeffers, "“And Their Children After Them': A Response to Reformed Baptist Readings of Jeremiah's New Covenant Promises," Ecclesia Reformanda 1.2 2009:126. Sometimes the text is cited without any indication of the potential problem it poses. For example, Berkhof simply states, "And in view of the rich promises in the Old Testament, Isa. 54:13; Jer. 31:34; Joel 2:28, it is inconceivable that they (children) would be excluded in the New Testament", Louis Berkhof, Manual of Christian Doctrine, Grand Rapids, MI: Wm B Eerdmans Publishing Company, 1933:320. Compare Louis Berkhof, Summary of Christian Doctrine, Grand Rapids, MI: Eerdmans, 1938:171; and Louis Berkhof, Systematic Theology, Grand Rapids, MI: Eerdmans, 1938:633. In other instances, the text is not brought up at all. For example, the well-known case for paedobaptism made by Pierre Charles Marcel does not even mention this text in his discussion of "The Unconverted in the Covenant and the Church", Pierre Charles Marcel, The Biblical Doctrine of Infant Baptism: Sacrament of the Covenant of Grace, trans. Philip Edgcumbe Hughes, London: J Clarke, 1953:124-136.

6 Richard L Pratt Jr., "Infant Baptism in the New Covenant," in The Case for Covenantal Infant Baptism, (ed.) Greg Strawbridge, Phillipsburg, NJ: Presbyterian and Reformed, 2003:161. Cf. Jeffrey D Niell, "The Newness of the New Covenant," in The Case for Covenantal Infant Baptism. (ed.) Gregg Strawbridge, Phillipsburg, NJ: Presbyterian and Reformed, 2003:129-130.

7 Geerhardus Vos, Reformed Dogmatics, (ed.) Richard B Gaffin and Richard de Witt; trans. Annemie Godbehere et al.; vol. 2; Bellingham, WA: Lexham Press, 2013:58-68.

8 Vos, Reformed Dogmatics, 59. Berkhof seems to follow Vos here directly and raises the same concerns, Berkhof, Systematic Theology, 276. Earlier, on p. 54, Vos says: "The most and best Reformed theologians answer: with the elect sinner." This understanding of Jeremiah 31:34 seems to go back at least as far as Augustine where he specifically discusses the meaning of "all, from the least unto the greatest of them" and concludes that it includes only the elect, Augustine of Hippo, "A Treatise on the Spirit and the Letter," in Saint Augustine: Anti-Pelagian Writings. (ed.) Philip Schaff; trans. Peter Holmes; vol. 5; A Select Library of the Nicene and Post-Nicene Fathers of the Christian Church, First Series; New York: Christian Literature Company, 1887:99-100). 
At the same time, he also says it is "with believers and their seed." $\mathrm{He}$ then goes on to say that the great difficulty of the doctrine of the Covenant of Grace lies "in reconciling these two aspects with each other." 10

Reformed Baptists also see this text as foundational. As noted by Neil GT Jeffers, this is seen perhaps most acutely in Samuel E Waldron's A Reformed Baptist Manifesto, which bases the entire argument for credobaptism on the interpretation of Jeremiah 31:34 as presenting a purely regenerate New Covenant community. ${ }^{11}$

Likewise, proponents of credobaptism from a New Covenant or Progressive Covenantalism perspective agree that this text is foundational. In the very popular Believer's Baptism, Wellum's chapter, "Baptism and the Relationship between the Covenants," represents the volume's theological defense of credobaptism. Wellum says that a successful argument for credobaptism must adequately respond to the paedobaptist claim that the New Covenant community continues to be mixed. ${ }^{12}$ In his critique of paedobaptism and positive case for credobaptism, nearly every major point in Wellum's argument hinges (directly or indirectly) on the claim that the New Covenant is an exclusively regenerate community. And, as he says elsewhere: "The best place to demonstrate this point is the famous new covenant text of Jeremiah $31 . " 13$ Wellum goes so far as to say that Jeremiah $31: 34$, and its putative teaching that the New Covenant community is purely regenerate, is "the heart of the credobaptist position" and "the heart of the baptismal divide."14 Thus, Wellum's central claim is, "Because the church, by its very nature, is a regenerate community, the covenant sign of baptism must only be applied to those who have come to faith in Christ." 15 And, perhaps more than any other single text, it is his interpretation of Jeremiah 31:34 that is most crucial for his argument. ${ }^{16}$

\section{Vos, Reformed Dogmatics, 59.}

10 Ibid. Compare the discussion of this difficulty within Reformed theology in Peter J Gentry and Stephen J Wellum, Kingdom through Covenant: A Biblical-Theological Understanding of the Covenants, Wheaton, IL: Crossway, 2012:65-71.

11 Samuel E Waldron with Richard C Barcellos, A Reformed Baptist Manifesto: The New Covenant Constitution of the Church, Palmdale, CA: Reformed Baptist Academic Press, 2004, cited in Neil GT Jeffers. “"And Their Children After Them': A Response to Reformed Baptist Readings of Jeremiah's New Covenant Promises." Ecclesia Reformanda 1.2 2009:126. Waldron says Jeremiah 31:34 is "the only passage in the Old Testament that clearly and explicitly speaks of the relationship of the Old and New Covenants", Waldron, A Reformed Baptist Manifesto, 67. See also David Kingdon, Children of Abraham: A Reformed Baptist View of Baptism, the Covenant, and Children, Cambridge: Carey Publications, 1973:34, 76.

12 "Ultimately, if Baptists want to argue cogently against the paedobaptist viewpoint and for a believer's baptism, we must, in the end, respond to this covenantal argument." Stephen J Wellum, "Baptism and the Relationship Between the Covenants," in Believer's Baptism: Sign of the New Covenant in Christ, (ed.) Thomas R Schreiner, Shawn D Wright, and E Ray Clendenen, Nashville, TN: B\&H Academic, 2006:106.

13 Gentry and Wellum, Kingdom through Covenant, 686.

14 Wellum, Baptism, 113. Compare his statement on p. 122: "What does this understanding of the nature of the church have to do with infant baptism? Everything." And on p. 150, he writes: "The real issue centers on whether there is a fundamental change in the structure and nature of the new covenant community in contrast to the old." Compare Gentry and Wellum, Kingdom through Covenant, 65, where, regarding Jeremiah 31:29-34, they write: "it is here that various understandings of the nature of the church begin to part paths." Also see Thomas R Schreiner and Shawn D Wright, 'Introduction,' in Believer's Baptism: Sign of the New Covenant in Christ, (ed.) Thomas R Schreiner, Shawn D Wright, and E Ray Clendenen, Nashville, TN: B\&H Academic, 2006:3.

15 Wellum, Baptism, 146. Cf. Gentry and Wellum, Kingdom through Covenant, 510.

16 In fact, his response to the paedobaptist argument of a mixed New Covenant community from the warning passages in Hebrews is simply to question the validity of that interpretation based on his understanding of Jeremiah 31:34, Wellum, Baptism, 160-61. In Kingdom through Covenant, Gentry and Wellum continue to employ Jeremiah 31:34 as the most foundational text for a credobaptist ecclesiology and sacramentology. "They base a key ecclesiological structural change from old covenant to new covenant primarily on 
Even credobaptist proponents coming from the very different hermeneutical tradition of dispensationalism acknowledge the central role of Jeremiah 31:34 and its description of the New Covenant community for the baptism debate. For example, John MacArthur has said that Jeremiah 31:34 and its supposed restriction of the covenant community to a purely regenerate membership is "...the watershed issue, I believe, on this whole discussion... The essence of the New Covenant is everybody in it knows God savingly." 17

Again, the paedo- vs. credobaptist debate is complex with a huge number of issues. However, a cursory survey of major representatives from the major positions reveals the central role of Jeremiah 31:34 and its statement that in the New Covenant, "all of them will know me, from the least of them to the greatest of them." Therefore it is surprising that there is relatively little discussion in this debate of what the quantifying phrase - "all of them ... from the least of them to the greatest of them" - means in light of its repeated and thematically linked uses in the context of Jeremiah's message. But before presenting a more contextually informed interpretation of this phrase in Jeremiah, it will be helpful to survey briefly two of the most common responses to the credobaptist argument from Jeremiah 31:34, as well as a third, more recently developed approach.

\section{Traditional Paedobaptist Responses}

One common response to a credobaptist reading of Jeremiah 31:34 is to move to other texts in order to argue that even the New Covenant community is mixed, especially the warning passages in Hebrews 6:4-6 and 10:28-29. These passages, they maintain, treat apostates who where never truly regenerate as, nevertheless, true covenant members. Here, the distinction between internal and external covenant membership is employed. ${ }^{18}$ It is argued that these texts present the New Covenant community as mixed; that is, as including those who are really covenant members, but who have never inwardly apprehended the saving benefits of Christ - regeneration, justification, and other benefits only enjoyed by the elect. So, it is argued, the New Covenant community is mixed and therefore, Jeremiah 31:34 cannot be teaching a purely regenerate membership (at least not before the return of Christ) to the exclusion of infants in believing households. ${ }^{19}$

Vos's Reformed Dogmatics, as noted above, offers an extensive discussion of this issue. While only citing the warning passages in Hebrews peripherally, Vos's resolution of the

Jer 31:29-34 ... If one scans the rest of this section of $K T C$ for other OT texts that support such a radical structural change, they will not be found. Thus, this seems to be a 'Jer 31-centered' ecclesiology. To put it another way, if Jer 31 can be shown to mean something other than what Gentry and Wellum take it to mean, the textual support for their radical structural change will be absent", Jonathan M Brack and Jared S Oliphint, "Questioning the Progress in Progressive Covenantalism: A Review of Gentry and Wellum's Kingdom Through Covenant," The Westminster Theological Journal. 76, no. 1 2014:205-206 (emphasis mine).

17 John F MacArthur, "Case for Believers' Baptism: The Credo Baptist Position” in RC Sproul and John F. MacArthur, The Baptism Debate, Orlando, FL: Ligonier Ministries, 1998. Accessed October 14, 2014, http://www.gty.org/resources/articles/a360/case-for-believers-baptism-the-credo-baptist-position. Cf. Bruce Ware, "Believers' Baptism View" in Baptism: Three Views. (ed.) David F Wright, 43-45 and Matthew W Waymeyer, A Biblical Critique of Infant Baptism, The Woodlands, TX: Kress Christian Publications, 2008:75-77.

18 For a very thorough discussion of this concept, see R Scott Clark, "Baptism and the Benefits of Christ: the Double Mode of Communion in the Covenant of Grace," Confessional Presbyterian, 2, 2006:3-19.

19 A more recent defense of paedobaptism along these lines can be seen in Bryan Holstrom, Infant Baptism and the Silence of the New Testament, Greenville, SC: Ambassador International, 2008:47. Cf. Philip Graham Ryken, Jeremiah and Lamentations: From Sorrow to Hope, Preaching the Word; Wheaton, IL: Crossway Books, 2001:472. 
problem posed by Jeremiah 31:34 is essentially the same. He concludes that while Jeremiah may be referring exclusively to the elect, the New Covenant community is mixed, nevertheless. Vos's treatment is of particular value since, in offering a solution to the difficulty of non-elect covenant membership supposedly posed by Jeremiah 31:34, he also marshals the writings of Olevianus, Witsius, Braun, Lampe, Mastricht, A Marck, Franken, A Brakel, Turretin, and Koelman. ${ }^{20}$ However, despite Vos's facility in the original languages and his breadth of secondary reading in Reformed dogmaticians, there is no discussion of what the quantifier means in the light of its parallel uses in Jeremiah and whether it actually refers to a purely regenerate New Covenant community. In fact, he proceeds with his discussion from the conviction that it does (citing in support Olevianus, Witsius, Mastricht, A Brakel, and others). ${ }^{21}$

Another common paedobaptist response, as hinted at above, is the claim that Jeremiah 31:34 does indeed teach a purely regenerate membership, but that this will only be realised when Christ returns at his second coming. Therefore, the nature of the New Covenant community before the return of Christ is still mixed and thus allows for non-regenerate infant members. ${ }^{22}$

Now, while these arguments may be sound, it cannot be denied that the most satisfying interpretation of Jeremiah 31:34 would be one that finds support from the immediate context as well. Moreover, these arguments tacitly capitulate to, or at least leave unchallenged, the assumption that "all of them ... from the least of them to the greatest of them" must be interpreted in absolute terms. That is, paedobaptists generally agree that Jeremiah 31:34 does in fact teach a purely regenerate New Covenant membership. They simply disagree about when that will be realised. It is in regard to these two points that the next proposal moves in the right direction.

A third, more recent, interpretation of Jeremiah 31:34, as it relates to New Covenant membership and the proper subjects of baptism, while noted by others, has been more fully developed by Neil GT Jeffers. ${ }^{23}$ His argument is more contextually based and challenges the assumption that Jeremiah intends to predict a purely regenerate New Covenant community, whether pre- or post-consummation. ${ }^{24}$ His approach is to interpret Jeremiah 31:31-34 alongside the parallel New Covenant promise in Jeremiah 32:37-41. Jeffers

20 Unfortunately, Vos does not provide references to particular texts from these authors. However, the place to which he is referring in Witsius seems to be Sacred Dissertations 2.24, especially sections 11-13.

21 Vos, Reformed Dogmatics, 58-68. More contemporary systematic theologies from authors on both sides of the baptism debate generally seem unconcerned with Jeremiah 31:34 as it relates to the nature of New Covenant membership and the proper subjects of baptism. Some representative credobaptist systematic theologies of which this is true include Millard J Erickson. Christian Theology, Grand Rapids, MI: Baker Academic, 2013, who doesn't even cite Jeremiah 31:34 at all, let alone in reference to ecclesiology and baptism, and Wayne A Grudem. Systematic Theology: An Introduction to Biblical Doctrine, Grand Rapids, MI: Zondervan, 2000, who cites the text twice (451-453 and 752), but in service of other points. Paedobaptist systematic theologies also generally seem uninterested in raising the issue with this particular text.

22 For example, Pratt writes: "We can have confidence that after Christ returns in glory, everyone in the new creation will have the law of God written on his or her heart... In this sense, we expect Jeremiah's prophecy to find complete fulfillment when Christ returns. At the present time, however, this expectation is only partially fulfilled" (Pratt, "Infant Baptism," 171. Compare Berkhof, Manual, 161). This interpretation even finds confessional support in the Geneva Confession of Faith, article IV in Church of Scotland, The Confessions of Faith and the Books of Discipline of the Church of Scotland, London: Baldwin and Cradock, 1831:132-133. This view goes back at least as far as Theodoret of Cyrrhus (c. 393-c. 460) quoted in Dean O Wenthe. Ancient Christian Commentary on Scripture, 12, Downers Grove, Ill: InterVarsity Press, 2009:217, citing $P G$ 81:668.

23 Jeffers, “And Their Children after Them," 125-152.

24 However, as will be discussed below, his argument does not actually necessitate this point. 
argues that in these parallel New Covenant promises, "from the least of them to the greatest of them" in Jeremiah 31:34 corresponds to "for their good and their children after them" in Jeremiah 32:39. Therefore, based on the parallel promise in the following chapter, he argues that Jeremiah 31:34 cannot be excluding children from the New Covenant community. ${ }^{25}$

Moreover, Jeffers' helpfully suggests that "all ... from the least of them to the greatest of them" need not refer to all without exception, but all without distinction, and employs this interpretation for a better understanding of New Covenant membership and the proper subjects of baptism. ${ }^{26}$ Jeffers also considers the use of this and similar phrases elsewhere in Jeremiah and other passages. However, his argument centres on the claim that "from the least of them to the greatest of them" in Jeremiah 31:34 is parallel to "their good and the good of their children" in Jeremiah 32:39. Therefore, his analysis of the phrase focuses on arguing that it expresses the nuance of age distinctions, thereby including covenant children. ${ }^{27}$ For this reason, Jeffers stops short of considering whether it is even exegetically viable at all to interpret the phrase as referring to a group about which something is exhaustively true - in this case, knowledge of the Lord. In fact, Jeffers actually suggests the possibility that Jeremiah 31:34 is saying that even infants will know the Lord based on the concept of 'seminal faith.' 28

25 Cf. Marcel, The Biblical Doctrine of Infant Baptism, 107; Sinclair Ferguson, "Believer's Baptism View: Infant Baptist Response" in Baptism: Three Views. (ed.) David F Wright, Downers Grove, Ill: IVP Academic, 2009:57-58; and Brack and Oliphint, "Questioning the Progress," 207, 209.

26 Jeffers notes what seems to be a pervasive absence of this observation in the relevant literature in service of its ecclesiological and sacramental implications (Jeffers, "And Their Children after Them," 142). It is interesting to note, however, that commentators from both sides of the debate interpreting the passage without a view to baptism seem consistently to characterise the main thrust of Jeremiah 31:34 to be the dissolution of class distinctions rather than a presentation of the necessary condition of New Covenant membership (more on this below). The latter interpretation seems to be offered only when the baptism debate is in view.

27 Similarly, Niell, "The Newness of the New Covenant," 51-55 very helpfully argues that other instances of the concept "least to the greatest" in Jeremiah and other passages (including the NT) show that the concern is 'classes' of people. However, it is not entirely clear how that is necessarily inconsistent with a credobaptist reading. In other words, it seems that the credobaptist can affirm that knowledge of the Lord will cut through the demographic boundaries characteristic of the Mosaic Covenant and that every member without exception will know the Lord savingly. This may be why the potential force of this point seems lost on Malone in his critique of Niell's argument. In fact he doesn't interact with Jeremiah's other uses of this quantifier at all, Malone, The Baptism of Disciples Alone, 247-248. Greg Welty seems to be the only one to respond directly to the idea that Jeremiah 31:34 is referring to "all types of people." However, he merely asserts that, since different classes of people were saved in the Mosaic Covenant (e.g. 'lowly Hanna,' citing 1 Sam. 1-2), that cannot be what Jeremiah 31:34 has in mind for the New Covenant. However, he overlooks the crucial concept of pervasiveness in the quantifying phrase in question. This is not surprising in light of the fact that he does not even acknowledge Jeremiah's other, thematically linked uses of the quantifier, which, as is argued below, consistently refer to a group about which something is pervasively, though not exhaustively true, Greg Welty, A Critical Evaluation of Paedobaptism, Fullerton, CA: Reformed Baptist Publications: 2001. Accessed October 15, 2014 at http://www.founders.org/library/welty.html.

28 Jeffers writes: "Even if it were concerned with every individual member of the New Covenant possessing the subjective knowledge of God, then infants and children should be included in that promise. This is not a difficulty for Reformed paedobaptists because of the systematic understanding of seminal faith in covenant children outlined later", Jeffers, "“And Their Children after Them,"” 143-144. Niell makes a similar move when he suggests that Jeremiah 31:34 can be referring to 'non-saving knowledge', Niell, "The Newness of the New Covenant," 153, fn. 37. Along these lines, there is a long-held view in paedobaptist traditions (Protestant and otherwise) that infants should be counted as believers by virtue of the faith of their parents, or at least, the 'disposition' of faith. For a discussion of this view from several different perspectives, as well as citations of proponents going back to the ancient church, see Herman Bavinck, Reformed Dogmatics: Holy Spirit, Church, and New Creation. (ed.) John Bolt and trans. John Vriend, vol. 4; Grand Rapids, MI: Baker Academic, 2008:522-525. But again, trying to fit infants into Jeremiah's New Covenant category of those who know the 
Again, without calling into question the merits of what this argument does have to offer, I want to go one step further and argue that, based on Jeremiah's previous uses of the quantifier, the New Covenant promise that "all of them will know me, from the least of them to the greatest of them" cannot be presenting a necessary condition or a sine qua non of New Covenant membership to the exclusion of infants in believing households.

\section{A Contextual Interpretation}

At the outset, it is interesting to note that the consensus of commentaries (even from Baptist traditions) seems to present the democratisation of the knowledge of the Lord beyond demographic boundaries as the main thrust of the promise in Jeremiah 31:34. ${ }^{29}$ Likewise, the standard lexicons and theological dictionaries describe the collocation generally as a merism, or, as the NIDOTTE states, an idiom used to refer to a group, "irrespective of race or prominence." ${ }^{30}$ It seems that it is only texts arguing for credobaptism that press Jeremiah 31:34 as a description of the necessary condition for New Covenant membership. More importantly, a survey of the standard reference material on Jeremiah 31:34 and the collocation in question reveals that they do not characterise it as quantifying a group for which a sine qua non of membership obtains. It turns out that this is for good reason, since Jeremiah employs thematically linked uses of this quantifier consistently in reference to a group about which something is pervasively, though not exhaustively true.

Lord is an implicit capitulation to the idea that the quantifier Jeremiah uses ("all ... from the least of them to the greatest of them") presents a group about which something is exhaustively true - in this case, knowledge of the Lord.

29 From the credobaptist side, see, for example, Elmer A Martens, Jeremiah, Believers Church Bible Commentary; Scottdale, PA: Herald Press, 1986:196; compare FB Huey, Jeremiah, Lamentations, vol. 16; The New American Commentary; Nashville: Broadman and Holman Publishers, 1993:286.

The classic Protestant paedobaptist interpretation is from John Calvin, Jeremiah and Lamentations, Crossway Classic Commentaries; Wheaton, IL: Crossway Books, 2000:188. Lundbom points out that commentators generally follow Calvin's interpretation of this phrase in Jeremiah 6:13 as transcending class distinctions, JR Lundbom, Jeremiah 1-20, AB 21A; New York, NY: Doubleday, 1999:430. Also see Matthew Poole, Annotations Upon the Holy Bible, vol. 2; New York: Robert Carter and Brothers, 1853:592; Carl Friedrich Keil and Franz Delitzsch, Commentary on the Old Testament, vol. 8; Peabody, MA: Hendrickson, 1996:283-284; JA Thompson, The Book of Jeremiah, NICOT; Grand Rapids, MI: Eerdmans, 1980:581; William Lee Holladay, Jeremiah: A Commentary on the Book of the Prophet Jeremiah, chapters 26-52, vol. 2; Hermeneia; Minneapolis: Fortress Press, 1989:198-199; Brueggemann, Walter, To Build, to Plant: A Commentary on Jeremiah 26-52, Grand Rapids: Eerdmans, 1991:72; Lundbom, Jeremiah 21-36, AB 21B New York, NY: Doubleday, 2004:470; Ryken, Jeremiah and Lamentations, 472.

Compare the NET note on Jeremiah 31:34 which says the phrase should be understood in light of its previous uses (citing 8:8-9; 5:1-5; 9:3-9) and explicitly describes the phrase as referring to "all without distinction." Biblical Studies Press, The NET Bible First Edition Notes, Biblical Studies Press, 2006. Also see Barclay M Newman, Jr. \& Philip C Stine, A Handbook on Jeremiah, UBS Handbook Series; New York: United Bible Societies, 2003:190-191. In reference to Jeremiah 6:13 (to which the note on the parallel phrase in Jer. 31:34 directs readers), they write: "From the least to the greatest (see also 8:10; 16:6; 31:34; 42:1) is a Hebrew way of including people of all social levels. Similarly from prophet to priest is inclusive, without suggesting different levels of status within the religious order." Beale connects Jeremiah 31:33-34 to Leviticus 26:9-12; Joel 2:28-29, and to Jesus' priesthood in the context of its quotation in Hebrews 8:8-12. From these connections he argues that the thrust of Jeremiah's promise is 'priestly democratization', GK Beale, A New Testament Biblical Theology: The Unfolding of the Old Testament in the New, Grand Rapids, MI: Baker Academic, 2011:731-736).

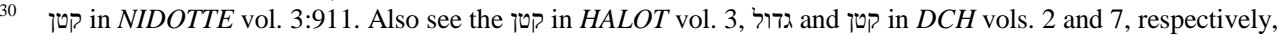

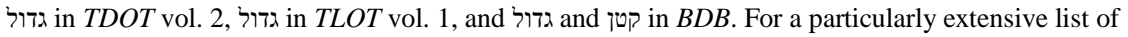
occurrences and nuances of this collocation, see קט in TDOT vol. 13. For an extensive discussion of merism in Hebrew, see Alexander M Honeyman, "Merismus in Biblical Hebrew," Journal of Biblical Literature, 71.1 1952:11-18, as well as Jože Krašovec, Der Merismus im Biblisch-Hebräischen und Nordwestsemitischen, Rome: Biblical Institute Press, 1977. 
The phrase, "all of them ... from the least of them to the greatest of them" has five parallels in the text preceding Jeremiah 31:34, each describing the apostate Mosaic Covenant community. ${ }^{31}$ In 5:4-5, Jeremiah speaks of the knowledge of the Lord among the 'poor' and the 'great.' He expects the poor to not have a knowledge of the Lord (v. 4) but is shocked to find that even the great do not know the Lord (v. 5). ${ }^{32}$ Jeremiah's description of the utter apostasy of the covenant community continues to 6:13 when God himself declares, "from the least of them to the greatest of them, everyone makes unjust profit; and from prophet to priest, everyone practices deceit." The next usage appears in 8:10 where again, God declares, "from least to greatest, everyone makes unjust profit; from prophet to priest, everyone practices deceit." In 9:3-6, the Lord declares in inverse parallelism, "they do not know me" (A, v. 3 [MT v. 2]) and "every brother utterly betrays and every friend goes about as a slanderer" (B, v. 4 [MT v. 3]). "Everyone deceives his friend" (B', v. 5 [MT v. 4]) and "they refuse to know me" (A', v. 6 [MT v. 5]). Finally, in 16:6, God says that the judgment for his covenant people's apostasy is that "great and small will die."

These passages clearly do not mean that no member of the Mosaic Covenant without exception knew the Lord or that every single Covenant Member (including the infant) had turned aside to unjust profit and deception. In other words, the collocation גדול + does not in those texts designate a group for which its predicate was the necessary condition of membership. If credobaptist proponents were to interpret this phrase consistently throughout the flow of Jeremiah's message and these previous uses were pressed as presenting the sine qua non of membership in the Mosaic Covenant community, that would mean anyone who knew the Lord, did not pursue unjust profit, or did not deceive and slander was not actually a covenant member. This would exclude Jeremiah himself and the entire Israelite remnant from being true members of the Mosaic Covenant. Clearly this cannot be what the phrase means. This calls into question the legitimacy of interpreting Jeremiah's use of this same phrase in 31:34 as presenting the sine qua non of New Covenant membership.

Additionally, there does not seem to be any indication that the meaning of this quantifying phrase suddenly shifts in the progression of Jeremiah's message. In fact, the phrase occurs later in Jeremiah at 42:1, 8 and 44:12 with the same force. That is, even these subsequent uses are in contexts where it seems clear that it does not mean all without exception. "All the people from the least to the greatest" in 42:1 are said to plead with the Lord in 42:2. Since all the people in this verse included children (see 41:16), it is doubtful that Jeremiah intended to say that every single member of that assembly without exception,

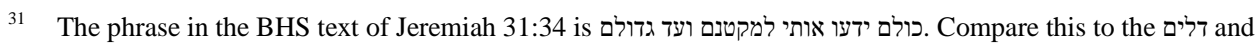

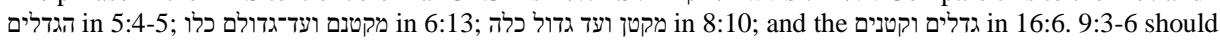

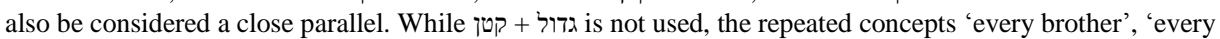
neighbour,' and the knowledge of the Lord provide strong thematic and verbal links between 9:3-6 and 31:34. For a list of the various forms in which this merism occurs elsewhere, see TLOT vol. 1, 303. This merism does appear in slightly different forms throughout Jeremiah (e.g. including prepositions vs. simple syndetic connection, the presence vs. absence of pronominal suffixes, etc.). However, these are common variations that do not change the fundamental unity of meaning between its thematically linked usages (see the discussion in TDOT vol. 13:399, compare Krašovec, Der Merismus, 140). Given the strong thematic ties to Jeremiah's repeated usage of this quantifying phrase (discussed below), it seems the burden of proof would fall on detractors to demonstrate that these slight differences undermine the basic unity of meaning. Furthermore, if the slight variations in the uses of this collocation are pressed to suggest a different meaning, that would contradict the fact that variations also occur even when we know they refer to the exact same group - e.g. the Mosaic Covenant community in the uses preceding Jer 31:34.

32 In addition to their conceptual parallel, Holladay notes that 'the least' and 'the greatest' in Jeremiah 31:34 also has a strong lexical tie to 'the poor' and 'the great' in 5:4-5 since these are the only two texts in Jeremiah where forgiveness is described with the word סלח, Holladay, Jeremiah, 199. 
including the infant, was engaged in a verbal plea. ${ }^{33}$ This same group is also in view when the phrase is used in $42: 8 .^{34}$ And 44:14 explicitly gives an exception to the phrase used in 44:12. The text says, "... all ... From the least to the greatest" would die by sword and famine (44:12), “...except those who escape" (44:14; compare verse 28).

There are also several other passages in the OT that employ this collocation in the same way. Of particular interest is Jonah 3:5, which says, "And the people of Nineveh believed God, proclaimed a fast, and put on sackcloth, from the greatest of them to the least of them." On the credobaptist reading, it seems this would have to mean that everyone, without exception, believed God and put on sackcloth, and anyone that did not (e.g. infants) was not really a Ninevite. ${ }^{35}$

In addition to the fact that previous uses cannot be understood as presenting a necessary condition of covenant membership, these previous uses are directly related to the parallel quantifier, Jeremiah 31:34. The intentional repetition of this quantifying phrase in Jeremiah contributes to a thematic progression culminating in the New Covenant promise in the Book of Consolation (Jeremiah 30-33), the conclusion of which has Jeremiah 31:31-34 as its chiastic centre. ${ }^{36}$ The content of the Book of Consolation is directly related to the preceding message of Jeremiah "... because it gives expression to hopes for the future rather than judgment which characterises earlier chapters". ${ }^{37}$ Lundbom points out that the poetic structure of the passage also serves to highlight this theme of contrast between the present state of affairs in Jeremiah's day and the future hope. ${ }^{38}$ Holladay notes that each section of 31:31-34 is chiastic, "the first section centering on the old covenant, the second on the new. ${ }^{39}$ In fact, this theme of contrast between the present dismal state of affairs and the future hope constitutes a major structuring element of the entire book. Jeremiah 1:10 introduces the two-fold message that God will both 'pluck up' and 'break down' but that he will also 'build' and 'plant.' After elaborating on God's judgment against covenantbreaking Israel who would be plucked up and broken down, we read in the Book of Consolation, containing the New Covenant promise, that God would again build and plant (Jeremiah 31:28). ${ }^{40}$

33 If they were included in some way, it is hard to see why they should be excluded from Jeremiah 31:34.

34 In fact, in 42:10, the New Covenant language of 31:28 is applied to this group that included the Israelite children.

35 However, since Jeremiah's own use is most important for understanding the meaning of $31: 34$, that is the focus of this article. For other OT and NT uses of this type of quantifier, see Gen. 19:4, 11; 27:15; Deut. 1:17; 1 Sam. 5:9; 25:36; 30:2, 19; 1 Kings 22:31; 2 Kings 23:2; 25:26; 1 Chron. 25:8; 2 Chron. 15:13; 18:30; 31:15; 34:30; Esth. 1:5, 20; Acts 8:11; 26:22; Heb. 8:11; Rev. 11:18; 13:6; 19:5, 18; 20:12.

36 The conclusion of the book of consolation contains five oracles of which Jer. 31:31-34 is the centre. "The first (vv. 23-26) and fifth (vv. 38-40) oracles are about Jerusalem. The second (vv. 27-30) and fourth (vv. 35-37) form a contrasting pair", Keown, Jeremiah, 126.

37 Thompson, The Book of Jeremiah, 551. Also see Gordon McConville, Exploring the Old Testament: The Prophets, vol. 4; London: Society for Promoting Christian Knowledge, 2002:60.

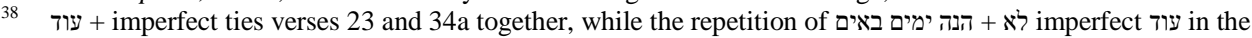
verse pairs 27, 29 and 31,34b create a structure that highlights the contrast between the old and new state of affairs, Jack R Lundbom, Jeremiah: A Study in Ancient Hebrew Rhetoric, Missoula, MT: Society of Biblical Literature, 1975:35. Cf. William McKane, A Critical and Exegetical Commentary on Jeremiah, vol. 2 International Critical Commentary; Edinburgh: T\&T Clark, 1986:817.

39 Holladay, Jeremiah, 197. He divides 31:31-34 into two sections: the prose section of 31-33a $\alpha$ and the poetic section of $33 \mathrm{a} \beta-34$.

40 Walter Brueggemann, Theology of the Old Testament: Testimony, Dispute, Advocacy, Minneapolis: Fortress Press, 1997:308. Compare Paul R House, Old Testament Theology, Downers Grove, Ill: InterVarsity Press, 1998:317. 
This overarching structure of Jeremiah's prophecy and the structure of the New Covenant promise in particular serve to tie it directly to the preceding descriptions of the Old. In other words, Jeremiah clearly seems to intend for his readers to interpret this phrase in 31:34 in connection with its preceding uses. But now we read of the hope for a future reversal of the pervasive lack of knowledge of the Lord among God's people. God uses the same language of 16:6, 9:3-6, 8:10, 6:13, and 5:4-5. However, this time, God declares that his people will know him - "all of them ... from the least of them to the greatest of them."

Thus, on a more contextual reading, it becomes clear that the Old/New Covenant contrast in Jeremiah 31:34 is between present pervasive lack of knowledge of the Lord and the future pervasive presence of the knowledge of the Lord. In the coming days the present situation in Israel would be flipped on its head. While at that time Jeremiah was amazed by the pervasive lack of the knowledge of the Lord even among the great, the time was coming when he could expect to find a pervasive presence of it even among the least. While at that time there was a pervasive lack of knowledge of the Lord among God's people that affected everyone without distinction, the days were coming when such knowledge would be poured out on all without distinction.

But, crucially, each instance of this quantifying phrase in the flow of Jeremiah's message designates a mixed community. In other words, the thing predicated of the group designated by the quantifying phrase "all ... from the least of them to the greatest of them" (e.g. not knowing the Lord, deceiving, slandering, or knowing the Lord) was not true of every single member of the group. So, while there are certainly profound new features in the New Covenant, Jeremiah's use of the same quantifying phrase in reference to both Old and New strongly suggests that he does not intend to posit faith as a sine qua non of membership to be one of those new features. Simply put, that's not Jeremiah's point.

When Jeremiah 31:34 is approached in this way, the paedobaptist does not have to hurry quickly to other passages that support a mixed New Covenant community (though that may be legitimate) or point out that the New Covenant community will be purely regenerate at the consummation (though that is true). There is no need to posit seminal faith, fides aliena, presumptive regeneration, or to reinterpret "knowledge of the Lord" in some 'non-saving' way in order to squeeze covenant children into the New Covenant promise of Jeremiah 31:34. Rather, the paedobaptist can simply interpret Jeremiah 31:34 consistently with the way Jeremiah invariably uses the quantifier throughout his prophesy - in reference to a community about which something is pervasively, though not exhaustively, true. If, on the on the other hand, credobaptists want to push this quantifier as demanding a necessary condition of New Covenant membership, they must show where in the context of Jeremiah's message the phrase picked up that notion which is absent from every other use.

\section{Conclusion}

When reading the main sources on the baptism debate, it does not take long to realise the central role played by Jeremiah 31:34 for the credobaptist argument that the New Covenant has a purely regenerate membership. However, when interpreted in light of the thematically linked uses of this quantifying phrase in the progression of Jeremiah's message, it becomes clear that Jeremiah does not intend to present knowledge of the Lord as a sine qua non of New Covenant membership to the exclusion of infants.

The Baptist may still seek to argue that the New Covenant community is not mixed. However, it seems clear that it can no longer be viably argued from this quantifying phrase in Jeremiah 31:34. If this phrase is to be used in defining the necessary condition(s) of New Covenant membership, the credobaptist will need to explain where that meaning comes 
from, given the numerous, consistent and thematically linked uses of the quantifier in the previous context, where that cannot be what it means. With the contextual evidence in view, it seems that the credobaptists turn out to be the ones who must account for the inconsistency between their view of the New Covenant community and Jeremiah's own consistent use of this phrase in reference to a mixed community - that is, a community about which something is pervasively, though not exhaustively, true.

\section{BIBLIOGRAPHY}

Augustine of Hippo 1887. “A Treatise on the Spirit and the Letter." Saint Augustine: AntiPelagian Writings. Edited by Philip Schaff, Translated by Peter Holmes. Vol. 5.

A Select Library of the Nicene and Post-Nicene Fathers of the Christian Church, First Series. New York: Christian Literature Company.

Bavinck, Herman 2008. Reformed Dogmatics: Holy Spirit, Church, and New Creation. Edited by John Bolt and Translated by John Vriend. Vol. 4. Grand Rapids, MI: Baker Academic.

Beale, Gregory K 2011. A New Testament Biblical Theology: The Unfolding of the Old Testament in the New. Grand Rapids, MI: Baker Academic.

Berkhof, Louis 1933. Manual of Christian Doctrine. Grand Rapids, MI: Eerdmans.

Berkhof, Louis 1938. Summary of Christian Doctrine. Grand Rapids, MI: Eerdmans.

Berkhof, Louis 1938. Systematic Theology. Grand Rapids, MI: Eerdmans.

Biblia Hebraica Stuttgartensia: SESB Version 2003. Electronic (ed.) Stuttgart: German Bible Society.

Botterweck, Gerhard Johannes, and Helmer Ringgren 1974. Theological Dictionary of the Old Testament. Vol. 2. Grand Rapids, MI: Eerdmans.

Botterweck, Gerhard Johannes, Helmer Ringgren, Heinz-Josef Fabry, and David E.

Green 2004. Theological Dictionary of the Old Testament. Vol. 13. Grand Rapids, MI: Eerdmans.

Brack, Jonathan M, and Jared S Oliphint 2014. "Questioning the Progress in Progressive Covenantalism: A Review of Gentry and Wellum's Kingdom Through Covenant." The Westminster Theological Journal. 76. 1:189-218.

Brown, Francis, Samuel Rolles Driver and Charles Augustus Briggs 2000. Enhanced

Brown-Driver-Briggs Hebrew and English Lexicon. Oak Harbor, WA:

Logos Research Systems.

Brueggemann, Walter 1991. To Build, to Plant: A Commentary on Jeremiah 26-52.

Grand Rapids: Eerdmans.

Brueggemann, Walter 1997. Theology of the Old Testament: Testimony, Dispute, Advocacy. Minneapolis: Fortress Press.

Calvin, John 2000. Jeremiah and Lamentations. Crossway Classic Commentaries;

Wheaton, IL: Crossway Books.

Church of Scotland 1831. The Confessions of Faith and the Books of Discipline of the

Church of Scotland. London: Baldwin and Cradock. 
Clark, R Scott 2006. "Baptism and the Benefits of Christ: the Double Mode of Communion in the Covenant of Grace," Confessional Presbyterian, 2:3-19. Available at http://www.cpjournal.com/wp-content/uploads/2007/06/CPJ2-RSClark.pdf.

Clines, David JA and John Elwolde 1995. The Dictionary of Classical Hebrew. Vol. 2. Sheffield: Sheffield Academic Press.

Clines, David JA, David Stec, Jacqueline CR de Roo and Helen Spurling 2010. The Dictionary of Classical Hebrew. Vol. 7. Sheffield: Sheffield Phoenix Press.

Erickson, Millard J 2013. Christian Theology. Grand Rapids, MI: Baker Academic. Ferguson, Sinclair B 2009. "Believer's Baptism View: Infant Baptist Response” in Baptism: Three Views. Edited by David F. Wright, 51-60. Downers Grove, Ill: IVP Academic.

Gentry, Peter J and Stephen J Wellum 2012. Kingdom through Covenant: A BiblicalTheological Understanding of the Covenants. Wheaton, IL: Crossway.

Grudem, Wayne A 2000. Systematic Theology: An Introduction to Biblical Doctrine. Grand Rapids, MI: Zondervan.

Harris, W Hall (ed.) 2006. The NET Bible First Edition Notes. Biblical Studies Press.

Holladay, William L 1989. Jeremiah: A Commentary on the Book of the Prophet Jeremiah, chapters 26-52. Vol. 2. Hermeneia; Minneapolis: Fortress Press.

Holstrom, Bryan 2008. Infant Baptism and the Silence of the New Testament. Greenville, SC: Ambassador International.

Honeyman, Alexander M 1952. "Merismus in Biblical Hebrew." Journal of Biblical Literature. 71.1:11-18.

House, Paul R 1998. Old Testament Theology. Downers Grove, Ill: InterVarsity Press. Huey, FB 1993. Jeremiah, Lamentations. Vol. 16. The New American Commentary; Nashville: Broadman and Holman Publishers.

Jeffers, Neil GT 2009. “'And Their Children After Them”: A Response to Reformed Baptist Readings of Jeremiah's New Covenant Promises." Ecclesia Reformanda, 1.2:125-152.

Jenni, Ernst and Claus Westermann 1997. Theological Lexicon of the Old Testament. Translated by Mark E. Biddle. Vol. 1. Peabody, MA: Hendrickson Publishers.

Keown, Gerald L, Pamela J Scalise, and Thomas G Smothers 1995. Jeremiah 26-52. Edited by John D. W. Watts. Vol. 27. Word Biblical Commentary; Waco, Tex: Word Books.

Kingdon, David 1973. Children of Abraham: A Reformed Baptist View of Baptism, the Covenant, and Children. Cambridge: Carey Publications.

Koehler, Ludwig, Walter Baumgartner, MEJ Richardson and Johann Jakob Stamm 1996. The Hebrew and Aramaic Lexicon of the Old Testament. Vol. 3. Leiden; New York: Brill.

Keil, Carl Friedrich and Franz Delitzsch 1996. Commentary on the Old Testament. Vol. 8. Peabody, MA: Hendrickson.

Krašovec, Jože 1977. Der Merismus im Biblisch-Hebräischen und Nordwestsemitischen. Rome: Biblical Institute Press.

Lundbom, Jack R 1975. Jeremiah: A Study in Ancient Hebrew Rhetoric. Missoula, MT: Society of Biblical Literature. 
Lundbom, Jack R 1999. Jeremiah 1-20. Vol. 21A. The Anchor Yale Bible. New York, NY: Doubleday.

Lundbom, Jack R 2004. Jeremiah 21-36. Vol. 21B. The Anchor Yale Bible. New York,

NY: Doubleday.

MacArthur, John F 1998. "Case for Believer's Baptism: The Credo Baptist Position.”

In R C Sproul and John F MacArthur. The Baptism Debate. Orlando, FL:

Ligonier Ministries. Available at http://www.gty.org/resources/articles/a360/casefor-believers-baptism-the-credo-baptist-position.

Malone, Fred A 2008. The Baptism of Disciples Alone: A Covenantal Argument for Credobaptism Versus Paedobaptism. Revised and expanded, 2nd edition. Cape Coral, FL: Founders Press.

Marcel, Pierre Charles 1953. The Biblical Doctrine of Infant Baptism: Sacrament of the

Covenant of Grace. Translated by Philip Edgcumbe Hughes. London: J Clarke.

Martens, EA 1986. Jeremiah. Believers Church Bible Commentary; Scottdale, PA: Herald Press.

McConville, Gordon 2002. Exploring the Old Testament: The Prophets. Vol. 4. London: Society for Promoting Christian Knowledge.

McKane, William 1986. A Critical and Exegetical Commentary on Jeremiah. Vol. 2. International Critical Commentary. Edinburgh: T\&T Clark.

Newman, Barclay M Jr. and Philip C Stine 2003. A Handbook on Jeremiah.

UBS Handbook Series. New York: United Bible Societies.

Niell, Jeffrey D 2003. "The Newness of the New Covenant.” In The Case for Covenantal Infant Baptism. Edited by Gregg Strawbridge, 127-155. Phillipsburg, NJ:

Presbyterian and Reformed.

Poole, Matthew 1853. Annotations upon the Holy Bible. Vol. 2. New York: Robert Carter and Brothers.

Pratt, Richard L Jr.2003. 'Infant Baptism in the New Covenant.' In The Case for Covenantal Infant Baptism. Edited by Gregg Strawbridge, 156-174. Phillipsburg, NJ: Presbyterian and Reformed.

Ryken, Philip Graham 2001. Jeremiah and Lamentations: From Sorrow to Hope. Preaching the Word; Wheaton, IL: Crossway Books.

Schreiner, Thomas R and Shawn D Wright 2006. "Introduction.” In Believer's Baptism: Sign of the New Covenant in Christ. Edited by Thomas R Schreiner, Shawn D Wright, and E Ray Clendenen. Nashville, TN: B\&H Academic.

Thompson, JA 1980. The Book of Jeremiah. The New International Commentary on the Old Testament. Grand Rapids, MI: Eerdmans.

Vangemeren, Willem A (ed.)1997. New International Dictionary of Old Testament Theology and Exegesis. Vol. 3. Grand Rapids, MI: Zondervan.

Vos, Geerhardus 2013. Reformed Dogmatics. Edited by Richard B Gaffin and Richard de Witt. Translated by Annemie Godbehere, Roelof van Ijken, Kim Batteau, Daan van der Kraan, and Harry Boonstra. Vol. 2. Bellingham, WA: Lexham Press.

Ware, Bruce A 2009. "Believer's Baptism View.” In Baptism: Three Views. Edited by David F. Wright, 19-50. Downers Grove, Ill: IVP Academic. 
Waymeyer, Matthew W 2008. A Biblical Critique of Infant Baptism. The Woodlands, TX: Kress Christian Publications.

Wellum, Stephen J 2006. "Baptism and the Relationship Between the Covenants." In Believer's Baptism: Sign of the New Covenant in Christ. Edited by Thomas R Schreiner, Shawn D Wright and E Ray Clendenen, 97-161, Nashville, TN: B\&H Academic.

Welty, Greg 2001. A Critical Evaluation of Paedobaptism. Fullerton, CA: Reformed Baptist Publications, Available at http://www.founders.org/library/welty.html

Wenthe, Dean O (ed.) 2009. Jeremiah, Lamentations. Vol. 12. Ancient Christian Commentary on Scripture. Downers Grove, Ill: InterVarsity Press.

Witsius, Herman 1823. Sacred Dissertations, on What Is Commonly Called the Apostles' Creed. Translated by Donald Fraser. Vol. 2. London: Khull, Blackie and Company. 